\title{
IAMJ
}

INTERNATIONAL

AYURVEDIC

MEDICAL JOURNAL

ISSN: 2320-5091

Impact Factor: 6.719

\section{RASAYANA AND DEGENERATIVE EYE DISORDERS}

\section{Sangram Singh Rajput ${ }^{1}$, Shiromani Mishra ${ }^{2}$, Ravindra Sharma ${ }^{3}$}

${ }^{1}$ P.G. Scholar, Department of Dravyaguna Vigyan, Govt. DhanwantariAyurved College, Ujjain, Madhya Pradesh, India

${ }^{2}$ Reader, Department of Dravyaguna Vigyan, Govt. DhanwantariAyurved College, Ujjain, Madhya Pradesh, India ${ }^{3}$ Lecturer, Department of Dravyaguna Vigyan, Govt. DhanwantariAyurved College, Ujjain, Madhya Pradesh, India

Corresponding Author: Sangramrajput1057@gmail.com

https://doi.org/10.46607/iamj09092021

(Published Online: September 2021)

Open Access

(C) International Ayurvedic Medical Journal, India 2021

Article Received:25/08//2021 - Peer Reviewed:04/2021 - Accepted for Publication:05/09/2021

\section{Check for updates}

\section{ABSTRACT}

As eyes are in continuous exposure to the light and face both anatomical as well as functional deterioration with increasing age, there is a high incidence of issues in visual functioning of the eye that affects day to day activities of the individual and has a great impact on the physical, social and mental state of a person. As with today's world, the intake of unhealthy food and improper lifestyle is the main cause of to produce Ama, which is the major cause of development of all the diseases including ocular disorders. Rasayana Chikitsa is well known for its effective and potential role in degenerative disorders.

Keywords: Rasayana, Degenerative eye disorders, Chyavanprasha Avaleha, Oxidative stress.

\section{INTRODUCTION}

Netra is the important sense organ of the body, and it should be of prime concern of every individual to take proper care of the eyesight. $R a$ sayana Chikitsa operates by maintaining the equilibrium of Doshas, Agni, Dhatus and proper ex- cretion of Mala along with a healthy state of mind. Rasayana Chikitsa emphasises on both treating the ailment and prevention of the disease. As eyes are in continuous exposure to the light and face both anatomical as well as functional 
deterioration with increasing age, there is a high incidence of issues in visual functioning of the eye that affects day to day activities of the individual and has a great impact on the physical, social and mental state of a person. The word Rasayana is made up of two words "Rasa" and "Ayana", which is taken as Rasa Gamanam i.e, transportation or transformation of theRasathus maintaining a proper state of all Dhatus. As with today's world, the intake of unhealthy food and improper lifestyle is the main cause for the production of Ama, which is the major cause of development of all the diseases including ocular disorders.RasayanaChikitsa is well known for its effective and potential role in degenerative disorders. Among the various classifications of the diseases, Swabhava Bala PravrittaVyadhi consists of Kshudha (hunger), Pipasa (thirst), Nidra (sleep), Jara (Ageing) and Mrityu (death). As these states cannot be cured completely problems like Jara can be delayed and problems occurring due to increasing age can be prevented.

\section{AIM \& OBJECTIVE:}

1. To explore Ayurvedic text to understand the concept of Rasayana in the management of degenerative eye disorders
2. To mention various drugs possessing Rasayana properties that can prevent various degenerative eye disorders

\section{MATERIAL AND METHODS:}

There is a various classification of Rasayana presents $\mathrm{n}$ the ancient texts:

(i) Kamya Rasayana- to fulfil a particular desire-

Prana Kamya, Medha Kamya, Srikamya

(ii) Naimittika Rasayana- used to treat the disease for example- Shilajtu in Prameha, Bhallataka in Amavata, Brahma Rasayana, Triphala Rasayana, etc.

(iii) Ajastrika Rasayana- used on regular basisKsheerghrita Upyoga

According to method:

(i) Kutipraveshika Rasayana - also known as in door therapy

(ii) Vatatapika Rasayana- also known as outdoor therapy

According to contents of Rasayana-

(i) Aushadha Rasayana

(ii) Ahara Rasayana

(iii) Achara Rasayana- various Hita Viharas are explained in the Samhita that acts as Chakshushya. For example,

\begin{tabular}{|l|l|}
\hline Padabhyanga & Chakshushya $^{1}$, Drishti Prasadana \\
\hline Chatradharana & Chakshushya $^{3}$ \\
\hline Padatra Dharana & Chakshushya $^{4}$, Chakshu Raksha \\
\hline Snana & SarvaIndriya Vibodhana $^{6}$ \\
\hline ShitenShirasahSnana(cold water head bath) & Chakshushya $^{7}$ \\
\hline Pada Prakshalana & Chakshu Prasadana $^{8}$ \\
\hline Chankramana & Indriya bodhanama $^{9}$ \\
\hline Anjana & \\
\hline
\end{tabular}

\section{According to mode of action:}

(i) Sanshodhana-applied for body purification, eg. Soma Rasayana

(ii) Sanshamana- used to pacify the vitiated Doshas inside the body, Nagbala Rasayana, Guduchi.

What is Ageing?

Ageing is the process of progressive loss of functional capacity and an increase in the risk of diseases that occurs with advancing age.There are different ways or types of ageing i.e, Successful ageing with good health without any disease or functional deficiency, ageing occurring with disease and functional decline ageing which includes poor cognition, immunological impairment, etc. 


\section{What is degeneration?}

Degeneration is the process of deterioration and loss of specialized function of the cells of a tissue or an organ. Degeneration can also be taken as retrogressive changes, reversible cell injury or non-lethal cell injury. As in degeneration, the nucleus of the cell remains alive it is possible to obtain the original status of the cell or tissue by removing the causative factor, unlike the cell death.

\begin{tabular}{|c|c|}
\hline \multirow[t]{3}{*}{ Conjunctiva } & Concretion \\
\hline & Pinguecula \\
\hline & Pterygium \\
\hline \multirow[t]{5}{*}{ Cornea } & Calcific band keratopathy \\
\hline & Arcus senilis \\
\hline & Terrien's ulcer \\
\hline & Salzmann nodular degeneration \\
\hline & Lipid keratopathy \\
\hline Lens & Cataract \\
\hline Vitreous & Vitreous degeneration, Vitreous detachment, \\
\hline \multirow[t]{6}{*}{ Retina } & Age related Macular Degeneration \\
\hline & Degenerative retioschisis \\
\hline & Paving stone degeneration \\
\hline & Peripheral reticulae cystoids degeneration \\
\hline & Microcystoid degeneration \\
\hline & Albinotic spot \\
\hline Refractive error & Presbyopia \\
\hline Temporal artritis & \\
\hline
\end{tabular}

Various Rasayana described in Charak Samhita:

\begin{tabular}{|l|l|}
\hline Chyavanaprasha Rasayana & Balamindriyanam $^{11} 73-17$ \\
\hline Amalaki Rasayana & Indriyabala Samudhita $^{12} 75-18$ \\
\hline Haritaki Rasayana & Sareerendriya Budhibala ${ }^{13} 76-19$ \\
\hline Amalaki Ghrita & Sthirendriyam cha Atibalendriyam $^{14} 2-5-23$ \\
\hline Amalakayas brahma rasayana & IndriyaBalapradam $^{15} 3-6-36$ \\
\hline Lauhadi rasayanam & Ati Balendriyam \\
\hline Dwiteya indrokta rasayanam $22-37$ \\
\hline
\end{tabular}

Gada Nigraha has stated that Triphala in the form of paste, powder and decoction is useful in all conditions of visual disturbances.

Various Rasa Aushadhis that act as Chakshushya:

\begin{tabular}{|l|l|}
\hline Swarna & Chakshushyam Ayushpradam $^{18}$ \\
\hline Yashada & Nayanamaya Nasakaram ${ }^{19}$ \\
\hline Kasis & Netryam (Rasa Ratna Sammuchaya) \\
\hline Khatika & Netraamaya Nishudhini( rasatarangani) $^{\text {Samudraphena }}$ \\
\hline Loha & Chakshushya $^{20}$ \\
\hline Gairik & Nayanamyaghnam (Rasa Tarangani) \\
\hline Srotanjan & Netryam \\
\hline
\end{tabular}




\section{Abhraka}

Tamra

\section{DISCUSSION}

As oxidative stress plays a major role in causing degenerative eye disorders by the production of free radicals mainly oxygen-free radicals known as Reactive oxygen species (ROS). This ROS is responsible for the development of diseases like age-related macular degeneration ${ }^{22}$, cataract $^{23}$, premature retinopathy $^{24}$, uveitis ${ }^{25}$, keratitis ${ }^{26}$, and ocular inflammation ${ }^{27}$. The Rasayana Dravya contains antioxidants that inhibit the process of oxidation and free radical production thus preventing the above-mentioned diseases. The superoxide dismutase present in the Rasayana drug catalyzes the dismutation of superoxide radicals into ordinary molecular oxygen. Thus, rebuilding the ageing tissue.Rasayana drug also possesses an immunomodulatory effect thus protecting against various primary and secondary eye disorders.Rasayana drugs are rich in vitamin $\mathrm{C}$ which aids in regulating the normal level of glutathione which is necessary for the normal metabolism of the lens. The tannins and polyphenol present in Rasayana drugs act as radioprotective agents thus preventing the risk of development of pterygium, cataract and catarrhal conjunctivitis. Cysteine present in Rasayana helps to repair lens protein.

\section{CONCLUSION}

As degenerative eye disorders are the major cause of visual disturbances and mostly their risk of occurrence increases with increasing age it is necessary to prevent them at an early stage. The unhealthy lifestyle and inclination of people towards the fast food that results in Mandagni and an increase in oxidative stress which are the major factor for degeneration. The Rasayana Chikitsa helps to treat as well as prevent these disorders. Rasayana drugs act as an immunomodulator, antioxidant, adaptogenic, cytoprotective, and increases blood circulation.

\section{REFERENCES}

Chakshushya ${ }^{21}$

Netramayeshu Uttamam

1. Sushruta Samhita By KavirajaAmbikadutta Shastri, Chaukhambha Publications,2014, Sutrasthana, Chapter 24 Shloka No. 70 Pg.No.136.

2. Charak Samhita, Vidyotini Hindi Vyakhya ByKashinath Pandey \&Gorakhnath Chaturvedi Edi 2014, ChaukhambaVishwabharti Publications, Sutrasthana Chapter 5, Shloka 91, Pg No. 129.

3. Sushruta Samhita By KavirajaAmbikadutta Shastri, Chaukhambha Publications,2014, Surasthana, Chapter 24 Shloka No. 76 Pg No. 136

4. Charak Samhita, Vidyotini Hindi Vyakhya ByKashinath Pandey \&Gorakhnath Chaturvedi Edi 2014, ChaukhambaVishwabharti Publications, Sutrasthana Chapter 5, Shloka 100, Pg No. 131.

5. Sushruta Samhita By KavirajaAmbikadutta Shastri, Chaukhambha Publications,2014, Surasthana, Chapter 24 Shloka No. 72 Pg No. 136

6. Sushruta Samhita By KavirajaAmbikadutta Shastri, Chaukhambha Publications,2014, Surasthana, Chapter 24 Shloka No. 57 Pg No. 135

7. Sushruta Samhita By KavirajaAmbikadutta Shastri, Chaukhambha Publications,2014, Surasthana, Chapter 24 Shloka No. 59 Pg No. 135

8. Sushruta Samhita By KavirajaAmbikadutta Shastri, Chaukhambha Publications,2014, Surasthana, Chapter 24 Shloka No. 70 Pg No. 136

9. Sushruta Samhita By KavirajaAmbikadutta Shastri, Chaukhambha Publications,2014, Surasthana, Chapter 24 Shloka No. 80 Pg No. 137.

10. Acharya Vaidya YT, Reprint Edition, CarakaSamhita of Agnivesha, Revised by Caraka and Dridhabala, Sutrasthana, matrasheetiyamadhyaya, Chapter 5, Verse16-17, Varanasi, Chaukambha Orientalia,2011,pg39.

11. Charak Samhita, Vidyotini Hindi Vyakhya ByKashinath Pandey \&Gorakhnath Chaturvedi Edi 2014, ChaukhambaVishwabharti Publications, Chikitsasthana Chapter 1-1, Shloka 73, Pg No. 17.

12. Charak Samhita, Vidyotini Hindi Vyakhya ByKashinath Pandey \&Gorakhnath Chaturvedi Edi 2014, ChaukhambaVishwabharti Publications, Chikitsasthana Chapter 1-1, Shloka 75, Pg No. 18.

13. Charak Samhita, Vidyotini Hindi Vyakhya ByKashinath Pandey \&Gorakhnath Chaturvedi Edi 2014, 
ChaukhambaVishwabharti Publications, Chikitsasthana Chapter 1-1, Shloka 76, Pg No. 19.

14. Charak Samhita, Vidyotini Hindi Vyakhya ByKashinath Pandey \&Gorakhnath Chaturvedi Edi 2014, ChaukhambaVishwabharti Publications, Chikitsasthana Chapter 1-2, Shloka 5, Pg No. 23.

15. Charak Samhita, Vidyotini Hindi Vyakhya ByKashinath Pandey \&Gorakhnath Chaturvedi Edi 2014, ChaukhambaVishwabharti Publications, Chikitsasthana Chapter 1-3, Shloka 6, Pg No. 36.

16. Charak Samhita, Vidyotini Hindi Vyakhya ByKashinath Pandey \&Gorakhnath Chaturvedi Edi 2014, ChaukhambaVishwabharti Publications, Chikitsasthana Chapter 1-3, Shloka 22, Pg No. 37.

17. Charak Samhita, Vidyotini Hindi Vyakhya ByKashinath Pandey \&Gorakhnath Chaturvedi Edi 2014, ChaukhambaVishwabharti Publications, Chikitsasthana Chapter 1-4, Shloka 24, Pg No. 56.

18. Dr.Damodarjoshi, Rasasastra (English edition): Chaukhambhaorientalia, Varanasi, reprint-2013, pp109

19. Dr.Damodarjoshi, RasaSastra (English edition): Chaukhambhaorientalia, Varanasi, reprint-2013, pp144

20. P.Himasagara Chandra Murthy, Rasasastra; Chowkhamba Sanskrit series office Varanasi, reprint2012 pp-415

21. Dr.Damodarjoshi, Rasasastra (English edition): Chaukhambhaorientalia, Varanasi, reprint 2013, pp.159

22. Mamura Y, Noda S, Hashizume K, et al. Drusen, choroidal neovascularization, and retinal pigment epithelium dysfunction in SOD1-deficient mice: a model of age-related macular degeneration. Proc Natl Acad Sci U S A. 2006; 103: 11282- 11287

23. Spector A. Oxidative stress-induced cataract: mechanism of action. FASEB J. 1995; 9: 1173- 1182

24. Niesman MR, Johnson KA, Penn JS. The therapeutic effect of liposomal superoxide dismutase in an animal model of retinopathy of prematurity. Neurochem Res. 1997; 22: 597-605.

25. Gritz DC, Montes C, Atalla LR, Wu GS, Sevanian A, Rao NA. Histochemical localization of superoxide production in experimental autoimmune uveitis. Curr Eye Res. 1991; 10: 927-931

26. Alio JL, Artola A, Serra A, Ayala MJ, Mulet ME. Effect of topical antioxidant therapy on experimental infectious keratitis. Cornea. 1995; 14: 175- 179.

27. Alio JL, Ayala MJ, Mulet ME, Artola A, Ruiz JM, Bellot J. Antioxidant therapy in the treatment of ex- perimental acute corneal inflammation. Ophthalmic Res. 1995; 27: 136- 143

\section{Source of Support: Nil Conflict of Interest: None Declared}

How to cite this URL: Ravindra Sharma et al: Rasayana And Degenerative Eye Disorders. International Ayurvedic Medical Journal \{online\} 2021 \{cited September 2021\} Available from:

http://www.iamj.in/posts/images/upload/2160_2164.pdf 